\title{
Ewelina Podgajna
}

\section{Janusz Stefaniak, Z naszych dziejów ojczystych. Wspomnienia nie tylko o Świdniku (1970-2015), Wydawnictwo Archidiecezji Lubelskiej „Gaudium”, Świdnik 2018, ss. 320}

N akładem Wydawnictwa Archidiecezji Lubelskiej „Gaudium” w 2018 roku ukazała się interesująca książka $Z$ naszych dziejów ojczystych. Wspomnienia nie tylko o Świdniku (1970-2015) autorstwa Janusza Stefaniaka. Książka jest urokliwym pamiętnikiem, dokumentem o życiu znanego i cenionego w Świdniku nauczyciela i pedagoga. Autor, skrzętnie opisując swój życiorys, przekazuje jednocześnie reprezentatywne świadectwo mentalności ludzi sobie współczesnych, a to wszystko na tle znamiennych realiów faktograficzno-historycznych. Książka jest ilustracją losów ich autora. Mamy tu do czynienia z lekturą pod wieloma względami unikatową, ponieważ autor chciał w niej pokazać nie tyle swoje życie, co historię Polski. Wspomnienia są ciekawe i ujmujące. Są w nich elementy powieści sentymentalnej (pierwsze zauroczenia i miłości), ciekawostki obyczajowe i towarzyskie. Najbardziej jednak autora zajmowały wydarzenia związane ze współczesną mu sytuacją polityczną i przełomowymi wydarzeniami z historii Polski i świata. Dzięki poszerzeniu perspektywy czasowej oraz komentarzom, rozważaniom i refleksjom autora wydarzenia przeszłe zyskują swój sens w teraźniejszości.

Książka jest rodzajem pamiętnika z czasów PRL - z wielką historią w tle i małymi troskami dnia codziennego w roli głównej. Autor zabiera czytelników w sentymentalną podróż do krainy swego dzieciństwa, młodości oraz okresu pracy zawodowej. Ukazuje przeszłość, ubarwiając ją pięknymi opisami przyrody i architektury. Bardzo istotnym elementem wspomnień są liczne podróże po kraju i za granicę. Większość wspomnień i relacji przeplata się ze wzmiankami historycznymi, gdyż autor był świadkiem znaczących przemian społeczno-politycznych.

Książka składa się ze wstępu, siedmiu rozdziałów, wzbogacona została także o indeks osobowy oraz zdjęcia z prywatnego archiwum autora. We wstępie wprowadza on czytelnika w swój świat i przedstawia losy swoje i najbliższej rodziny, wszystko to 
przeplecione trudami życia dnia codziennego za rządów Władysława Gomółki. Kolejne rozdziały w sposób chronologiczny przedstawiają kolejne lata życia autora, z których dowiadujemy się, co miało wpływ na zainteresowanie historią Polski. Na kartach książki Stefaniak skrupulatnie przedstawił czytelnikowi to, w jaki sposób ukształtował swoją postawę społeczną, wartości moralne i religijne. Wynika z nich, że niewątpliwy wpływ na młodego autora miał Kościół katolicki i wartości chrześcijańskie. W młodości pilnie uczestniczył w lekcjach religii, a od piątej klasy był ministrantem w parafii w Kazimierzówce koło Świdnika.

$\mathrm{W}$ rozdziale drugim autor opisał wspomnienia związane z podjęciem pracy zarobkowej w 1976 roku w Lubelskich Zakładach Naprawy Samochodów (LZNS), a którą zakończył w 1984 roku. W rozdziale trzecim opisał lata studiów historycznych na Uniwersytecie Marii Curie-Skłodowskiej w Lublinie w latach 1978-1983. Łączenie pracy zawodowej ze studiami było nader trudnym wyzwaniem. Wybrany kierunek studiów spotęgował zamiłowanie do historii i do zgłębiania tajników i zawiłości historycznych, zarówno w Polsce, jak i na świecie. Janusz Stefaniak rozbudził swoją pasję badawczą i współcześnie może pochwalić się pokaźnym dorobkiem naukowym. Publikował artykuły w monografiach naukowych i na łamach znanych czasopism naukowych, między innymi: „Dzieje Najnowsze Polski”, „Studia Historyczne”, „Teki Archiwalne”, „Annales UMCS" i wielu innych. W jego dorobku znajduje się ponad sto publikacji naukowych i popularnonaukowych. W latach 1984-2008 podjął pracę nauczyciela historii w Szkole Podstawowej nr 1 (gimnazjum) w Świdniku, co opisał w rozdziale czwartym. Zwieńczeniem wysiłku naukowego Janusza Stefaniaka była obrona 26 września 1995 roku dysertacji doktorskiej zatytułowanej Polityka władz państwowych PRL wobec prasy katolickiej w latach 1945-1953, promotorem rozprawy był profesor Zygmunt Mańkowski. Janusz Stefaniak na kartach kolejnych rozdziałów opisywał ewolucję swoich zainteresowań naukowych, a także rozliczne pasje podróżnicze.

Niewątpliwym atutem książki jest fakt, iż autor pomimo poruszania wątków z życia prywatnego $\mathrm{z}$ dużym dystansem i dyskrecją wspomina o swoich osobistych problemach czy relacjach, tak aby nikogo nie urazić. Ukazuje pewne cechy naszego społeczeństwa w okresie PRL i w latach transformacji ustrojowej Polski. Wspomnienia napisane w tak przyjętej konwencji niewątpliwie zachęcają czytelnika do sięgnięcia po książkę. Lektura jest pełna wspomnień i historii, poprzez które możemy poznać autora. Mały niedosyt czytelnika może budzić fakt, iż Stefaniak mało miejsca poświęcił okresowi lat 1980-1982, tak istotnemu z punktu widzenia historii Świdnika oraz całej Polski. Strajki w Wytwórni Sprzętu Komunikacyjnego w Świdniku, zakładach lotniczych w Świdniku 8 lipca 1980 roku były początkiem Lubelskiego Lipca.

Książkę warto polecić wielu kręgom odbiorców. Jest interesująca, autor dowiódł, że takie wartości, jak: wiedza, wykształcenie, wierność zasadom wybranego systemu wartości, bez względu na zawirowania dziejowe i polityczne, wysoki poziom kultury osobistej, umiłowanie ojczyzny, wrażliwość społeczna - mają wymiar ogólnohumanistyczny, utylitarny i zasługują na poszanowanie. Są to niewątpliwie wartości uniwersalne, o których często we współczesnym świecie się zapomina. 